\title{
Erratum to: Educational guidance on water under the paradigm of complexity as a result of a comparative study between Spain and Mexico
}

José Gutiérrez Pérez ${ }^{1}$ and Laura Galván Pérez ${ }^{1 a}$,

${ }^{I}$ Department of Research Methodology and Diagnosis in Education. University of Granada. Faculty of Education Science, Campus Cartuja, 18011, Granada

Original article:

MATEC Web of Conferences 26, 01101 (2016), DOI: 10.1051/shsconf/20162601101

The last author of the article should be Laura Galván Pérez. 